\title{
Poticanje samoreguliranoga učenja - uloga nekih sociodemografskih čimbenika, učiteljskih percepcija o poučavanju i učenju, predanosti poslu i sagorijevanja na poslu
}

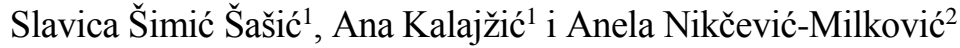 \\ ${ }^{1}$ Sveučilište u Zadru, Odjel za izobrazbu učitelja i odgojitelja, Zadar, Hrvatska \\ ${ }^{2}$ Sveučilište u Zadru, Odjel za nastavničke studije u Gospiću, Gospić, Hrvatska
}

\section{Sažetak}

Samoregulirano učenje (SRU) postalo je važan obrazovni cilj, a budući da ovisi o kontekstu u kojemu se događa, učitelji imaju važnu ulogu u poticanju razvoja učinkovitih strategija samoregulacije učenja. Cilj provedenoga istraživanja bio je ispitati učiteljsko poticanje SRU-a i njegov odnos s nekim sociodemografskim obilježjima učitelja (spol, radni staž, obrazovna razina), učiteljskim percepcijama o poučavanju i učenju, predanošću poslu i sagorijevanjem na poslu. Istraživanje je provedeno na uzorku od 299 učitelja razredne i predmetne nastave. Primijenjeni su sljedeći mjerni instrumenti: upitnik sociodemografskih obilježja, Skala poticanja samoreguliranoga učenja, Upitnik učiteljskih percepcija o poučavanju i učenju, Skala učiteljske predanosti i Oldenburški upitnik sagorijevanja. Rezultati su pokazali da učitelji poticanje SRU-a u suvremenoj nastavi smatraju važnim te da potiču SRU u radu s učenicima. Poučavanje i učenje dominantno percipiraju kao proces osnaživanja i poticanja razvoja učenika (učeniku usmjerene aktivnosti), što predstavlja odmak od tradicionalnih aktivnosti usmjerenih na učitelja. Nisu utvrđene razlike u poticanju SRU-a s obzirom na sociodemografska obilježja učitelja, ali utvrđene su neke razlike u učiteljskim percepcijama, predanosti i sagorijevanju. Utvrđena je povezanost poticanja SRU-a i dominantne percepcije poučavanja i učenja te predanosti poslu i sagorijevanja na poslu. Najsnažniji su prediktori poticanja SRU-a predanost školi i učenicima te percepcija poučavanja i učenja kao procesa osnaživanja i poticanja razvoja učenika.

Ključne riječi: poticanje samoreguliranoga učenja, predanost poslu, sagorijevanje na poslu, sociodemografska obilježja učitelja, učiteljske percepcije o poučavanju i učenju

\section{Uvod}

Vrijeme u kojemu živimo zahtijeva od učenika da budu sposobni regulirati vlastito učenje ne samo tijekom školovanja, nego i nakon školovanja. Učenici čije je

Slavica Šimić Šašić, Sveučilište u Zadru, Odjel za izobrazbu učitelja i odgojitelja, Franje Tuđmana 24i, 23000 Zadar. E-pošta: ssimic@unizd.hr 
učenje samoregulirano (SRU) ostvaruju pozitivnije obrazovne ishode, uspješniji su u rješavanju problema, imaju bolje akademsko postignuće, intrinzično su motivirani i pokazuju veći interes pri rješavanju zadataka (Zimmerman, 2002). Međutim, istraživanja pokazuju da učenje bitnoga dijela učenika nije optimalno samoregulirano jer im nedostaju znanja i vještine potrebni za učinkovito upravljanje vlastitim učenjem (Kramarski i Michalsky, 2009). Dio studija potvrđuje da s dobi i s razvojem kognitivnih sposobnosti dolazi do razvojne progresije u SRU-u (Duckwort i sur., 2009; Paris i Winograd, 2001). S druge strane, dio studija ukazuje na stagnaciju ili čak pad u periodu rane i kasne adolescencije (Brković i sur., 2012; NikčevićMilković i Tatalović Vorkapić, 2020; Raffaelli i sur., 2005; Šimić Šašić, 2012). Većina učitelja suglasna je s time da se učenicima treba pomoći da njihovo učenje postane samoregulirano, međutim, osjećaju se nesigurno u vezi s time kako to napraviti (Dignath-van Ewijk i van der Werf, 2012). Boekaerts (2002) smatra da u procesu promjene tradicionalnih uloga učitelja i učenika u razredu ključnu ulogu igra razumijevanje dinamike SRU-a i dinamike kreiranja okruženja za učenje koje će poticati SRU.

SRU samousmjeravajući je proces u kojemu učenici svjesno planiraju i prate vlastite kognitivne, ponašajne i afektivne procese važne za uspješno obavljanje akademskih aktivnosti (Zimmerman i Schunk, 2001). Ono uključuje procese postavljanja specifičnih, bliskih ciljeva, usvajanja učinkovitih strategija postizanja ciljeva, nadgledanja napredovanja u učenju, restrukturiranja fizičkoga i socijalnoga konteksta u skladu s vlastitim ciljevima, samovrednovanja, atribuiranja uzroka vlastitoga (ne)uspjeha u učenju, prilagodbu strategija za buduće učenje (Zimmerman, 2002). Prilikom definiranja samoga konstrukta većina je istraživača suglasna s time da je SRU multidimenzijski proces koji uključuje osobne (kognitivne i emocionalne), ponašajne i kontekstualne komponente (Zimmerman, 1998). Termin SRU i modeli SRU-a nastali su uglavnom unutar socijalno-kognitivne perspektive te Hadwin i Oshige (2011) smatraju da socijalni kontekst ima ključnu ulogu u oblikovanju i utjecaju na SRU. Empirijska istraživanja tradicionalno su bila usmjerena na osobne ili motivacijske faktore i njihov utjecaj na kognitivnu ili metakognitivnu samoregulaciju, podcjenjujući tako utjecaj konteksta (Leutwyler i Magg Merki, 2009). Dio istraživanja bio je usmjeren na proučavanje intervencija u razredu koje mogu potaknuti SRU. Zaključci proizašli iz tih istraživanja ukazuju na to da učitelji mogu utjecati na SRU na različite, direktne i indirektne načine: poučavanjem učenika učinkovitim strategijama učenja (kognitivnim i metakognitivnim: planiranje, nadgledanje napretka i razumijevanja, vrednovanje, modifikacija učeničkih uvjerenja, ciljeva, suočavanje s negativnim emocijama itd.) ili strukturiranjem okruženja učenja da bi učenici imali prilike sami otkriti učinkovite strategije učenja (kroz tipove zadataka, autoriteta, nagrađivanja, metoda grupiranja, vrednovanja, modifikacijom međuljudskih odnosa itd.) (Boekaerts i Corno, 2005; Dignath i Buettner, 2008; Dignath-van Ewijk i van der Werf, 2012; Montalvo i Torres, 2004; Paris i Winograd, 2001; Zumbrunn i sur., 2011). Socijalno-kognitivna perspektiva u poticanju SRU-a naglašava važnost modeliranja, prilika za vođeno uvježbavanje i 
povratnih informacija u nastavi. Perry i suradnici (2006) navode da učenici razvijaju učinkovite forme SRU-a kad su uključeni u rad na kompleksnim, smislenim zadacima, kad odlučuju o vlastitome učenju, načinu vrednovanja, kad rade u grupama i traže povratnu informaciju od vršnjaka te kad vrednuju svoje učenje. U takvome kontekstu učitelji osiguravaju da učenici steknu sadržajna znanja i znanja o strategijama koja im trebaju za samostalno funkcioniranje te da razvijaju svoje sposobnosti birajući izazovne zadatke. Učitelji radije vode nego da upravljaju učenjem učenika, koriste neprijeteće postupke vrednovanja koji učenike potiču da ostanu usmjereni na vlastiti napredak i da na pogreške gledaju kao na prilike za učenje. S druge strane, u razredima u kojima su zadaci usmjereni na specifične vještine učenici imaju ograničene mogućnosti izbora, kontrole izazova, vrednovanja procesa učenja te imaju manje mogućnosti za razvoj SRU-a. U takvoj je situaciji vjerojatnije da će učenici razviti defanzivne, samootežavajuće pristupe učenju. Iako istraživanja učinkovitosti programa za poticanje SRU-a ukazuju na to da je eksplicitno poučavanje efikasnim strategijama SRU-a učinkovitije nego samo strukturiranje okruženja učenja (Kramarski i Michalsky, 2009), Dignath-van Ewijk i van der Wert (2012) utvrdile su da učitelji radije potiču SRU osiguravajući učenicima autonomiju nego poučavajući ih strategijama učenja.

Istraživanja pokazuju da spremnost učitelja na poticanje SRU-a kod učenika ovisi o nekim učiteljskim karakteristikama. Dio tih istraživanja bio je usmjeren na povezanost između učiteljskih uvjerenja, znanja i učiteljske prakse. Spruce i Bol (2015) utvrdili su da ta tri konstrukta nisu usklađena. Učitelji iskazuju pozitivna vjerovanja o SRU-u, ali znanja o SRU-u i njihova primjena u razredu uglavnom su nedostatni. Dignath-van Ewijk i van der Wert (2012) utvrdile su da učitelji pokazuju pozitivniji stav prema konstruktivizmu nego prema SRU-u, pojmove samoregulirano učenje i učiti kako učiti doživljavaju kao odvojene pojmove, SRU povezuju s poticajnim okruženjem, a učiti kako učiti s poučavanjem strategija učenja.

Učiteljske percepcije o poučavanju i učenju odnose se na znanja i vjerovanja o poučavanju i učenju (Pajares, 1992) i imaju snažan utjecaj na ono što učitelj radi u razredu, odnosno na način na koji konceptualizira poučavanje (Brody, 1998, prema Kramarski i Michalsky, 2009; Pajeres, 1992; Woolfolk Hoy i sur., 2006). Istraživanja su pokazala da će učitelji koji imaju pozitivna vjerovanja o SRU-u vjerojatnije i poticati SRU kroz svoje poučavanje (Dignath-van Ewijk i van der Wert, 2012; Lombaerts i sur., 2009; Vandevelde i sur., 2012). Učiteljske percepcije o poučavanju i učenju smještene su na kontinuumu od aktivnosti usmjerenih na učitelja do aktivnosti usmjerenih na učenika. Na jednome kraju kontinuuma naglasak je na direktnoj transmisiji informacija od učitelja učeniku (učenik je pasivan u vlastitoj konstrukciji znanja i uglavnom je izložen frontalnomu poučavanju). Sljedeća razina na kontinuumu odnosi se na vođenje i modeliranje učitelja koji je posrednik između materijala i učenika (učenik je izložen eksplicitno elaboriranim informacijama, objašnjenjima koje daje učitelj). Sljedeći stadij označava osnaživanje i razvoj učenika (učenici su izloženi strategijama poučavanja koje uvažavaju različite potrebe učenika). Na drugome kraju kontinuuma naglasak je na učeničkoj konstrukciji znanja 
(učenik je odgovoran za svoje učenje, a učitelj potiče aktivne strategije učenja) i taj stadij predstavlja najvišu razinu aktivnosti usmjerenih na učenika (Kramarski i Michalsky, 2009). Pristup usmjeren na učitelja povezan je s površinskim pristupom učenju, a pristup usmjeren na učenika s dubinskim pristupom učenju učenika (Trigwell i sur., 1999) i većim zadovoljstvom poučavanjem (Trigwell i Prosser, 2004). Učenici koji iskuse pristup usmjeren na učenika imaju više prilika za aktivno učenje, povećanu autonomiju i ovladavanje učenjem (Lea i sur., 2003). Zohar (2004) izvještava da većina učitelja, posebice početnici, percipira proces poučavanja i učenja kao učitelju usmjerene aktivnosti, što može ometati razvoj SRU-a. Učiteljska se vjerovanja mogu mjeriti na različite načine, a najčešće se koriste samoprocjene. U novije se vrijeme kao analitičko sredstvo za razumijevanje učiteljskih uvjerenja koriste metafore. Metafore se mogu definirati kao samorazumljive analogije koje maštovito dovode $u$ vezu jedan predmet poimanja s drugim (Domović i Vizek Vidović, 2013, str. 497). To su širi konstrukti unutar kojih ljudi organiziraju svoje razmišljanje i iz kojih planiraju svoje akcije u različitim okruženjima u kojima sudjeluju, uključujući i način poučavanja nastavnika (Massengill i sur., 2008). Autori su utvrdili vrlo šarolike metafore o poučavanju, pri čemu su najčešće one tradicionalne koje poučavanje i učenje vide kao prijenos znanja, a učenike kao pasivne primatelje informacija ili čak kao „zatočenike” (Massengill i sur., 2008; Saban i sur., 2007). Usporedbe učiteljskih uvjerenja mjerenih pomoću metafora i upitnika ukazuju na kontradiktorne rezultate. Rezultati prikupljeni upitnicima ukazuju na izraženiji pristup usmjeren na učenika, dok rezultati prikupljeni pomoću metafora ukazuju na pristup usmjeren na učitelja (Domović i Vizek Vidović, 2013; Šimić Šašić i sur., 2018).

Hargreaves (2005) navodi da učiteljska obilježja poput spola, dobi, učiteljskoga iskustva, faze profesionalnoga razvoja i slično mogu utjecati na implementaciju SRU-a u razredu. Međutim, rezultati istraživanja nisu konzistentni. Lombaerts i suradnici (2009) utvrdili su da spol učitelja u osnovnoj školi nema značajan utjecaj na poticanje SRU-a, dok su neki drugi autori pokazali da učiteljice više koriste postupke koji potiču SRU (Elmas i sur., 2011; Yan, 2017). Peeters i suradnici (2015) konstatirali su da je manje vjerojatno da će stariji učitelji podržavati SRU. Lombaerts i suradnici (2007) pokazali su da nastavničko iskustvo utječe na poučavanje metakognicije u razredu, dok je Yan (2017) utvrdio da nastavničko iskustvo nije značajan prediktor poticanja SRU-a. Yan (2017) utvrdio je i da učitelji u osnovnoj školi percipiraju više koristi od SRU-a nego učitelji u srednjoj školi. Ranija istraživanja SRU-a provođena su uglavnom na starijim učenicima (viših razreda osnovne i srednje škole) i ukazivala su na to da mlađa djeca mogu imati poteškoća u primjeni kognitivnih i metakognitivnih strategija te da se samoregulacija učenja povećava tijekom osnovne škole i postaje učinkovita na kraju osnovnoškolske dobi (Dignath i sur., 2008). Novija pak istraživanja ukazuju na to da se važan pomak u samoregulaciji događa između predškolske dobi i šestoga razreda te da učenici osnovne škole imaju više koristi od poticanja SRU-a nego srednjoškolci (De Smul i sur., 2018). Istraživanja pokazuju da postoje razlike u poticanju SRU-a između 
nastavnika na različitim razinama obrazovanja. Nastavnici u višim razredima osnovne škole (engl. middle school) i u srednjoj školi nude prilike za samoregulaciju učenja, ali rijetko je direktno poučavanje. Iako učenici viših razreda osnovne škole imaju koristi od eksplicitnoga poučavanja, učitelji ga rijetko rutinski integriraju u poučavanje. Učitelji u nižim razredima osnovne škole (do 6. razreda) u najvećoj mjeri potiču samoregulaciju učenja (Moos i Ringdal, 2012). Autori zaključuju da unutar različitih skupina nastavnika postoje individualne razlike u poticanju samoregulacije učenja, a njih u najvećoj mjeri pripisuju nastavničkim uvjerenjima. Učiteljice rjeđe od učitelja poučavanje vide kao direktnu transmisiju znanja te je vjerojatnije da će usvojiti praksu orijentiranu na učenike (OECD, 2009). Šimić Šašić i suradnice (2018) mjerile su učiteljska uvjerenja kvalitativno pomoću metafora i kvantitativno pomoću upitnika te su utvrdile da nijedna mjera nije povezana $\mathrm{s}$ učiteljskim stažem. Učitelji predmetne nastave više su konstruktivistički orijentirani (metafore) od učitelja razredne nastave, a pristup usmjeren na učenika (upitnik) izraženiji je kod učitelja u višemu zvanju (mentori i savjetnici).

Zahtjevi za poticanje SRU-a novi su izazov za učitelje koji zahtijeva više uključenosti i uloženoga napora u kvalitetno poučavanje da bi se postigli optimalni ishodi učenja. Uključenost $\mathrm{i}$ napor $\mathrm{u}$ promoviranju kvalitetnoga poučavanja odražavaju se kroz učiteljsku predanost poslu, školi, učenicima i profesiji (Tsui i Cheng, 1999). Učiteljska predanost značajan je prediktor učinkovitosti škole, učiteljskoga zadovoljstva poslom, ostajanja u profesiji, uspješnosti u poslu, inovacija i integriranja novih ideja u praksu, učeničkoga postignuća i stavova prema školi (Thien i sur., 2014), kao i poticanja SRU-a (De Smul i sur., 2018). S druge strane, pojačani zahtjevi na poslu jedan su od važnih izvora stresa u radu za učitelje, pa tako i sagorijevanja na poslu. Demerouti i Bakker (2008, prema Burić i Slišković, 2018) sagorijevanje na poslu konceptualiziraju pomoću dimenzija iscrpljenosti i otuđenosti. Iscrpljenost se definira kao posljedica intenzivnoga, fizičkoga, afektivnoga i kognitivnog stresa, a otuđenost se odnosi na vlastitu distanciranost od posla. Stres i sagorijevanje na poslu rezultiraju fizičkim, psihološkim i ponašajnim promjenama, a između ostaloga utječu i na radnu učinkovitost. Učitelji se ne mogu posvetiti svojemu poslu, što utječe na kvalitetu poučavanja, komunikaciju s učenicima, razredno ozračje i učenički napredak (Koludrović i sur., 2009) te poticanje SRU-a (Serratore, 2015). Vandevelde i suradnici (2012) izvješćuju da su nedostatak vremena, pritisak na poslu i razlike među učenicima čimbenici koji ometaju poticanje SRU-a. Rezultati istraživanja o odnosu predanosti i sagorijevanja na poslu i sociodemografskih obilježja nastavnika također nisu konzistentni. Dio istraživanja ukazuje na manju predanost muškaraca i nastavnika s više staža (Guarino i sur., 2006; Ingersoll i sur., 1997; Rots i sur., 2014), dok Fresko i suradnici (1997) zaključuju da spol, nastavnički staž i razina obrazovanja nisu povezani s predanošću te da je učinak tih varijabli eventualno indirektan preko zadovoljstva poslom ili profesionalne slike o sebi. Sagorijevanje, odnosno depersonalizacija izraženija je kod muškaraca (Domović i sur., 2010; Kuzijev i Topolovčan, 2013; Özer i Beycioglu, 2010). Učitelji s više godina staža pokazuju više razine iscrpljenosti i otuđenosti 
(Domović i sur., 2010; Slišković i sur., 2016). Kuzijev i Topolovčan (2013) te Koludrović i suradnice (2009) utvrdili su veće sagorijevanje na poslu kod učitelja predmetne nastave, dok Domović i suradnice (2010) nisu utvrdile razlike s obzirom na razinu obrazovanja.

Cilj ovoga istraživanja bio je ispitati učiteljsko poticanje SRU-a i njegov odnos s nekim sociodemografskim karakteristikama učitelja (spol, radni staž, obrazovna razina - učitelj razredne/predmetne nastave), učiteljskim percepcijama (uvjerenjima) o poučavanju i učenju, predanošću poslu i sagorijevanjem na poslu. Specifični problemi bili su: a) ispitati razinu učiteljske procjene važnosti poticanja SRU-a u suvremenoj nastavi, samoprocjene poticanja SRU-a u radu s učenicima, učiteljske percepcije o poučavanju i učenju te predanosti poslu i sagorijevanja na poslu, kao i razlike u tim varijablama s obzirom na spol, radni staž i razinu obrazovanja (učitelji razredne/predmetne nastave); b) ispitati prediktivnu vrijednost sociodemografskih varijabli, učiteljskih percepcija o poučavanju i učenju, predanosti poslu i sagorijevanja u objašnjenju poticanja SRU-a. Očekujemo da učitelji prepoznaju važnost, ali da slabije potiču SRU, da percipiraju poučavanje i učenje na tradicionalan način te da su predani svojemu poslu i doživljavaju nisku razinu sagorijevanja. Zbog kontradiktornih nalaza dosadašnjih istraživanja i različite kategorizacije razina obrazovanja u Hrvatskoj u odnosu na neke druge države (npr. SAD, otkud je većina istraživanja) ne očekuju se razlike u poticanju SRU-a s obzirom na spol, nastavnički staž i razinu obrazovanja. Očekuje se da će poticanje SRU-a biti pozitivno povezano s konstruktivističkim percepcijama poučavanja i učenja i predanošću poslu, a negativno sa sagorijevanjem na poslu te se očekuje značajan doprinos mjerenih varijabli u objašnjenju poticanja SRU-a (posebice učiteljskih uvjerenja).

\section{Metoda}

\section{Ispitanici}

Istraživanje je provedeno na uzorku od 299 učitelja osnovne škole s područja Splitsko-dalmatinske (9 škola), Zadarske (4 škole) i Ličko-senjske županije (2 škole). Od ukupnoga broja ispitanika u uzorku su bile 254 žene $(85.23 \%)$ i 44 muškarca $(14.77 \%)$. Učitelja razredne nastave bilo je 105 (35.23\%), a učitelja predmetne nastave 191 (64.09\%), dok su 2 učitelja (0.67 \%) označila da rade i u razrednoj i predmetnoj nastavi. Prosječna dob ispitanika bila je 41.19 godina. Do 5 godina radnoga staža imala su $73(24.58 \%)$ učitelja, 6 - 15 godina $102(34.34 \%), 16-30$ godina $91(30.64 \%), 31$ - 40 godina $29(9.76 \%)$ i preko 40 godina radnoga staža 2 $(0.67 \%)$ učitelja. 


\section{Mjerni instrumenti}

\section{Upitnik za mjerenje sociodemografskih obilježja učitelja}

Ispitani su spol, dob, radni staž i obrazovna razina: razredna/predmetna nastava.

\section{Skala poticanja samoreguliranoga učenja}

Konstruirana je za potrebe ovoga istraživanja i sastojala se od 29 tvrdnji. Tvrdnje su producirane na temelju modela SRU-a i literature o učiteljskim aktivnostima važnima za poticanje SRU-a te su se odnosile na usklađivanje poučavanja $\mathrm{s}$ interesima $\mathrm{i}$ iskustvom učenika, poticanje postavljanja ciljeva, planiranja, nadgledanja i samoevaluacije učenja, rješavanja problema, pozitivnoga stava prema učenju, atribuiranja (ne)uspjeha, korištenja učinkovitih strategija učenja itd. Učitelji su trebali procijeniti koliko je ponašanje ili proces izrečen u svakoj tvrdnji važan za suvremenu nastavu te koliko se tvrdnja odnosi na njih (1 - uopće nije važno / uopće se ne odnosi na mene, 5 - jako je važno / u potpunosti se odnosi na mene). Primjeri su tvrdnji „Zajedno s učenicima postavljati ciljeve učenja”, „Poticati učenike na planiranje i upravljanje vlastitim učenjem".

Faktorska analiza na zajedničke faktore (uz Varimax rotaciju i karakteristični korijen veći od 1) za procjenu važnosti poticanja SRU-a pokazala je dvofaktorsku strukturu (a za procjenu vlastitoga poticanja SRU-a trofaktorsku strukturu), s time da je većina tvrdnji imala zasićenja na dvama (ili na svim trima) faktorima. Zbog poteškoća $u$ interpretaciji dobivenih faktora i usporedivosti rezultata provedene su faktorske analize $\mathrm{s}$ brojem faktora fiksiranim na $1 \mathrm{i}$ sve su tvrdnje imale zadovoljavajuća faktorska zasićenja. Postotak objašnjene varijance u prvome slučaju bio je $46.66 \%$, a u drugome $48.60 \%$. Sve su tvrdnje imale zadovoljavajuću povezanost s ukupnim rezultatom, a koeficijenti pouzdanosti (Cronbachova alfa) iznosili su .96 i .97.

Upitnik učiteljskih percepcija o poučavanju i učenju (Kramarski i Michalsky, 2009)

Originalni se upitnik sastoji od 4 tekstualne i 4 slikovne metafore koje se odnose na četiri razine učiteljskih percepcija na kontinuumu od aktivnosti usmjerenih na učitelja do aktivnosti usmjerenih na učenika. $U$ ovome su istraživanju korištene 4 tekstualne metafore: „Učenik je poput prazne posude koju treba napuniti.” transmisija znanja od učitelja prema učeniku; „Učenik je poput turista na vođenoj turi.” - vođenje i modeliranje; „Učenik je poput biljke koju treba njegovati da bi rasla i cvjetala." - osnaživanje i razvoj učenika; „Učenik je poput samostalnoga planinara." - konstrukcija znanja. Učitelji su na skali od pet stupnjeva trebali procijeniti koliko se slažu s navedenim tvrdnjama (1 - uopće se ne slažem, $5-u$ potpunosti se slažem). 
Skala učiteljske predanosti (Thien i sur., 2014)

Skala se sastoji od 13 tvrdnji, a mjeri 4 faktora: predanost školi, predanost učenicima, predanost poučavanju i predanost profesiji. Učitelji su pomoću petodijelne skale trebali procijeniti koliko se slažu s navedenim tvrdnjama (1 - uopće se ne slažem, 5 - u potpunosti se slažem).

Faktorskom analizom na zajedničke faktore (uz Varimax rotaciju i karakteristični korijen veći od 1) utvrđena je dvofaktorska struktura u kojoj su uglavnom tvrdnje koje mjere predanost školi i učenicima imale zasićenje na prvome, a tvrdnje koje mjere predanost poučavanju i profesiji na drugome faktoru. Prva tvrdnja nije imala zadovoljavajuće zasićenje nijednim faktorom, dok su 9. i 13. tvrdnja imale zasićenja na obama faktorima. Analize pouzdanosti pokazale su zadovoljavajuće koeficijente pouzdanosti (Cronbachova alfa) za supskalu Predanost školi i učenicima (4 tvrdnje; .74) i Predanosti poučavanju i profesiji (6 tvrdnji; .78). Tvrdnje 1, 5 i 8 izostavljene su prilikom formiranja ukupnoga rezultata. Primjeri su tvrdnji za Predanost školi i učenicima „Svi učenici mogu uspjeti i moja je misija pobrinuti se za njihov uspjeh” te za Predanost poučavanju i profesiji „Postati učitelj najbolja je odluka koju sam donijela/-o u životu".

Upitnik učiteljskih percepcija o poučavanju i učenju i Skalu učiteljske predanosti nezavisno su s engleskoga jezika prevela dva istraživača te je usklađen konačni prijevod.

Oldenburški upitnik sagorijevanja (Demerouti i Bakker, 2008, prema Burić i Slišković, 2018)

Upitnik su na uzorku hrvatskih nastavnika validirale Burić i Slišković (2018). Sastoji se od 16 tvrdnji i mjeri otuđenost („Ponekad mi je muka od mojih radnih zadataka”) i iscrpljenost („,Ima dana kad se osjećam iscrpljeno i prije nego što dođem na posao"). Učitelji su trebali procijeniti koliko se slažu s navedenim tvrdnjama od 1 - uopće se ne slažem do 5 - u potpunosti se slažem. Koeficijenti pouzdanosti (Cronbachova alfa) supskala otuđenosti i iscrpljenosti iznosili su .74 i .79.

\section{Postupak}

Istraživanje je provedeno uz suglasnost ravnatelja škola i učitelja koji su sudjelovali u istraživanju. Upitnici su učiteljima podijeljeni uz pomoć stručnih suradnika u školama. Sudjelovanje je bilo dobrovoljno i anonimno, a ispunjavanje upitnika trajalo je petnaestak minuta.

\section{Rezultati}

U Tablici 1. prikazana je deskriptivna statistika za mjerene varijable. 


\section{Tablica 1.}

Pokazatelji deskriptivne statistike za poticanje SRU-a, učiteljske percepcije o poučavanju i učenju, predanost poslu i sagorijevanje na poslu

\begin{tabular}{lccccc}
\hline Varijable & $M$ & $S D$ & raspon & asimetričnost & spljoštenost \\
\hline $\begin{array}{l}\text { Poticanje samoreguliranoga } \\
\text { učenja - važnost }\end{array}$ & 4.58 & 0.40 & $3.17-5.00$ & -1.11 & 0.78 \\
$\begin{array}{l}\text { Poticanje samoreguliranoga } \\
\text { učenja - samoprocjena }\end{array}$ & 4.52 & 0.43 & $2.83-5.00$ & -1.05 & 1.08 \\
$\begin{array}{l}\text { Transmisija znanja } \\
\text { Modeliranje }\end{array}$ & 2.97 & 1.27 & $1.00-5.00$ & -0.16 & -1.01 \\
Osnaživanje & 3.05 & 1.16 & $1.00-5.00$ & -0.23 & -0.67 \\
Konstrukcija znanja & 4.30 & 0.82 & $1.00-5.00$ & -1.24 & 1.56 \\
Predanost školi i učenicima & 3.03 & 1.12 & $1.00-5.00$ & -0.22 & -0.53 \\
Predanost poučavanju i profesiji & 4.21 & 0.61 & $1.25-5.00$ & -0.90 & 1.71 \\
Otuđenost & 4.02 & 0.75 & $1.83-5.00$ & -0.52 & -0.49 \\
Iscrpljenost & 2.11 & 0.60 & $1.00-4.13$ & 0.17 & -0.65 \\
& 2.48 & 0.67 & $1.00-4.38$ & -0.10 & -0.45 \\
\hline
\end{tabular}

Kolmogorov-Smirnovljevim testom utvrđeno je da distribucija rezultata ne odstupa značajno od normalne za otuđenost i iscrpljenost. Za ostale varijable distribucija rezultata odstupala je od normalne, ali vrijednosti asimetričnosti i spljoštenosti bile su u prihvatljivim granicama pa se u obradi podataka koristila parametrijska statistika. Učiteljske procjene važnosti i samoprocjene poticanja SRUa izrazito su visoke (pomaknute prema višim vrijednostima). Najizraženija je percepcija „Učenik je poput biljke koju treba njegovati da bi rasla i cvjetala”, a koja se odnosi na potrebu osnaživanja i poticanja razvoja učenika. Učitelji pokazuju relativno visoku predanost poslu i relativno nisku razinu sagorijevanja.

Testirane su razlike u poticanju SRU-a, učiteljskim percepcijama, predanosti poslu i sagorijevanju s obzirom na spol, radni staž i razinu obrazovanja (učitelji razredne/predmetne nastave). Iako je u uzorku bilo puno manje učitelja u odnosu na učiteljice, Levenov test pokazao je da su varijance homogene, izuzev varijanci varijable predanost školi i učenicima, te je za nju korišten Mann-Whitneyev test. Pokazalo se da razlike nisu statistički značajne. Utvrđene su statistički značajne razlike s obzirom na spol u otuđenosti $\left(t=4.12 ; p=0.00 ; M_{\mathrm{m}}=2.45 ; M_{\check{z}}=2.05\right)$ te predanosti poučavanju i profesiji $\left(t=-3.15 ; p=0.00 ; M_{\mathrm{m}}=3.69 ; M_{\check{z}}=4.08\right)$. Učiteljice su predanije poučavanju i profesiji, a učitelji su više otuđeni. Da bismo testirali značajnost razlika s obzirom na učiteljski staž, učitelji su prema stadiju razvoja karijere podijeljeni u tri grupe: a) do 5 godina staža, b) 6 - 15 godina staža i c) preko 15 godina staža. Utvrđene su statistički značajne razlike u učiteljskim percepcijama (modeliranje), predanosti poučavanju i profesiji te otuđenosti na poslu s obzirom na učiteljski staž. Za modeliranje su utvrđene statistički značajne razlike $\left(F_{(2,282)}=5.54, p=0.00 ; M_{1}=3.38 ; M_{2}=3.09: M_{3}=2,81\right)$ između učitelja s najmanje i učitelja s najviše staža. Učitelji s do 5 godina učiteljskoga staža u većoj mjeri poučavanje vide kao vođenje i modeliranje. Nadalje, utvrđene su razlike u predanosti 
poučavanju i profesiji $\left(F_{(2,282)}=3.14, p=0.04 ; M_{1}=4.19 ; M_{2}=3.90 ; M_{3}=4.02\right) \mathrm{i}$ otuđenosti $\left(F_{(2,279)}=3.62, p=0.02 ; M_{1}=1.95 ; M_{2}=2.20 ; M_{3}=2.13\right)$ između učitelja s najmanje i učitelja sa 6 - 15 godina staža. Najmanju razinu predanosti poučavanju i profesiji te najvišu razinu otuđenosti doživljavaju učitelji sa 6 - 15 godina radnoga staža. Kad je riječ o razlikama s obzirom na razinu obrazovanja (razredna/predmetna nastava), utvrđene su statistički značajne razlike u predanosti školi i učenicima $(t=$ $\left.-2.31 ; p=0.01 ; M_{\mathrm{r}}=4.32 ; M_{\mathrm{p}}=4.15\right)$, predanosti poučavanju i profesiji $(t=2.15$; $\left.p=0.03 ; M_{\mathrm{r}}=4.15 ; M_{\mathrm{p}}=3.95\right)$, otuđenosti (zbog nehomogene varijance računan je Mann-Whitneyev test; $Z=-2.73 ; p=0,01$; Suma rangova $G_{\mathrm{r}}=12052.50$; Suma rangova $\left.G_{\mathrm{p}}=27568.50\right) \mathrm{i}$ iscrpljenosti $\left(t=-2.26, p=0.02 ; M_{\mathrm{r}}=2.37 ; M_{\mathrm{p}}=2.55\right)$. Više razine predanosti navode učitelji razredne nastave, a sagorijevanja na poslu učitelji predmetne nastave.

Nadalje, željelo se ispitati povezanost između poticanja SRU-a i sociodemografskih obilježja učitelja, učiteljskih percepcija, predanosti poslu i sagorijevanja na poslu. Iz koeficijenata korelacija (Tablica 2.) vidljivo je da je poticanje SRU-a povezano samo s osnaživanjem, kao mjerom učiteljskih percepcija, predanošću poslu i sagorijevanjem na poslu.

Učitelji koji smatraju da je poticanje SRU-a važno u suvremenim školama te $\mathrm{i}$ sami kod učenika potiču SRU poučavanje i učenje vide kao proces osnaživanja i poticanja razvoja učenika, predaniji su svojemu poslu i doživljavaju manje sagorijevanja na poslu.

Nakraju, ispitana je prediktivna vrijednost sociodemografskih varijabli, učiteljskih percepcija o poučavanju i učenju, predanosti poslu i sagorijevanja $u$ objašnjenju poticanja SRU-a. Provedene su hijerarhijske regresijske analize s poticanjem SRU-a (važnost i samoprocjena) kao kriterijskim varijablama, a sociodemografske varijable (spol, staž i razina obrazovanja - 1. korak), učiteljske percepcije o poučavanju i učenju (2. korak) te predanost i sagorijevanje na poslu (3. korak) bile su prediktorske varijable (Tablica 3.).

Uključeni prediktori objasnili su $24 \%$ varijance procjene važnosti poticanja SRU-a i $22 \%$ varijance poticanja SRU-a kod učitelja. Sociodemografske varijable nisu značajni prediktori, objašnjavaju samo $2 \%$, odnosno $1 \%$ varijance. Učiteljske percepcije o poučavanju i učenju objašnjavaju dodatnih $9 \%$ i $7 \%$ varijance kriterija. Za procjenu važnosti poticanja SRU-a značajni su prediktori transmisija znanja i osnaživanje, a za samoprocjenu poticanja SRU-a osnaživanje. Nešto veći postotak varijance kriterija ( $13 \%$ i $14 \%$ ) objašnjavaju predanost i sagorijevanje, s time da je jedini značajan prediktor predanost školi i učenicima. U zadnjemu koraku regresijske analize značajni su prediktori procjene važnosti SRU-a učiteljske percepcije (transmisija, modeliranje $\mathrm{i}$ osnaživanje) te predanost školi i učenicima, a samoprocjene poticanja SRU-a osnaživanje te predanost školi i učenicima. 


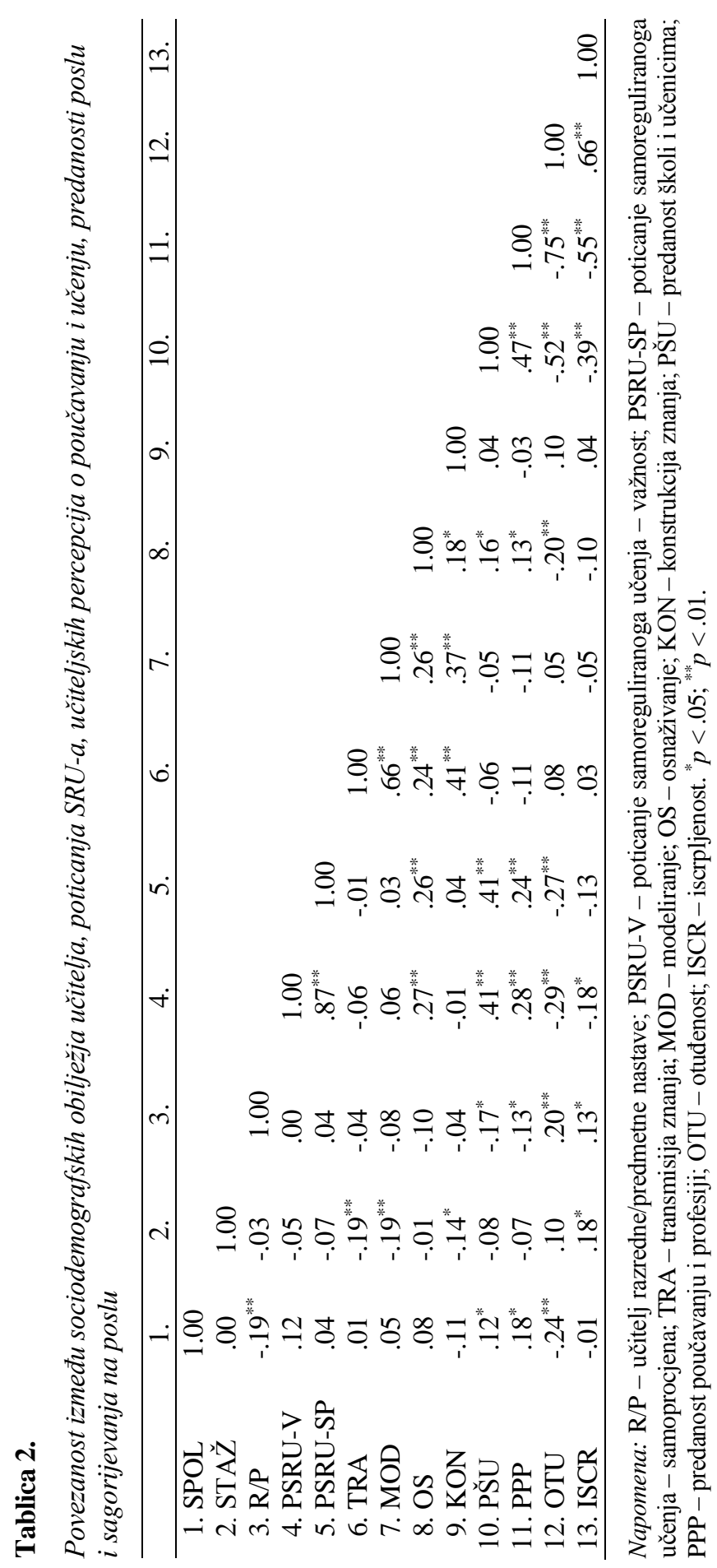




\section{Tablica 3.}

Rezultati hijerarhijskih regresijskih analiza za poticanje SRU-a (važnost i samoprocjena) kao kriterijskih varijabli (u zagradama su navedeni koeficijenti u završnome koraku analize)

\begin{tabular}{lll}
\hline & PSRU-V & PSRU-SP \\
\hline Prediktori & $\boldsymbol{\beta}$ & $\boldsymbol{\beta}$ \\
\hline 1. korak & $.13(.04)$ & $.11(.04)$ \\
Spol & $-.05(-.02)$ & $-.02(-.01)$ \\
Staž & $.03(.09)$ & $.01(.10)$ \\
R/P & .02 & .01 \\
\hline$R^{2}$ & - & - \\
$\Delta R^{2}$ & & \\
\hline 2. korak & $-.21^{*}\left(-.18^{*}\right)$ & $-.13(-.07)$ \\
TRA & $.11\left(.18^{*}\right)$ & $.04(.09)$ \\
MOD & $.29^{* *}\left(.22^{* *}\right)$ & $.25^{* *}\left(.19^{* *}\right)$ \\
OSN & $-.01(-.04)$ & $.06(.02)$ \\
KON & $.11^{* *}$ & $.08^{*}$ \\
\hline$R^{2}$ & $.09^{* *}$ & $.07^{*}$ \\
$\Delta R^{2}$ & & $.35^{* *}$ \\
\hline 3. korak & $.33^{* *}$ & .13 \\
PSSU & .12 & -.04 \\
PPP & -.01 & .15 \\
OTU & .05 & $.22^{* *}$ \\
ISCR & $.24^{* *}$ & $.14^{* *}$ \\
\hline$R^{2}$ & $.13^{* *}$ & \\
$\Delta R^{2}$ & &
\end{tabular}

Napomena: R/P - učitelj razredne/predmetne nastave; PSRU-V - poticanje samoreguliranoga učenja važnost; PSRU-SP - poticanje samoreguliranoga učenja - samoprocjena; TRA - transmisija znanja; MOD - modeliranje; OS - osnaživanje; KON - konstrukcija znanja; PŠU - predanost školi i učenicima; $\mathrm{PPP}$ - predanost poučavanju i profesiji; OTU - otuđenost; ISCR - iscrpljenost. ${ }^{*} p<.05 ;{ }^{* *} p<.01$.

\section{Rasprava}

U provedenome je istraživanju utvrđeno da učitelji razredne i predmetne nastave poticanje SRU-a smatraju vrlo važnim za suvremenu nastavu. Slično, a suprotno očekivanjima, visoko su procijenili i vlastito poticanje SRU-a u radu s učenicima. S obzirom na to da su podaci prikupljeni pomoću samoprocjene, visoke vrijednosti ne iznenađuju jer su učitelji (kao i ljudi općenito) skloni davanju društveno prihvatljivih procjena i sebe procjenjuju pozitivnije nego što to, primjerice, procjenjuju učenici. Kad analiziramo učiteljske percepcije o poučavanju i učenju mjerene pomoću metafora koje ispod praga svijesti daju dublji uvid u učiteljske percepcije srži poučavanja i učenja, vidimo da učitelji učenje i poučavanje percipiraju kao proces osnaživanja i poticanja razvoja učenika. Taj dio kontinuuma odnosi se na aktivnosti usmjerene na učenika (učenici su izloženi strategijama poučavanja koje uvažavaju različite potrebe učenika). Sljedeća je percepcija 
poučavanja i učenja kao procesa vođenja i modeliranja, u kojemu je učenik izložen eksplicitnim informacijama i objašnjenjima učitelja. Taj dio kontinuuma ukazuje na aktivnosti usmjerene na učitelja. Zatim slijedi uvjerenje da je učenik odgovoran za svoje učenje, a učitelj potiče aktivne strategije učenja (najviša razina aktivnosti usmjerenih na učenika), dok su najniže vrijednosti za uvjerenje da je poučavanje transmisija znanja (tradicionalan pristup usmjeren na učitelja). Slično nepodudaranje između učiteljskih uvjerenja mjerenih pomoću skala procjene i metaforama utvrdile su Dignath-van Ewijk i van der Wert (2012). Učitelji su se slagali s konstruktivističkim stajalištem o poučavanju i učenju, ali birali su metafore koje ukazuju na aktivnosti orijentirane na učitelja (modeliranje). Optimistična je spoznaja u našemu istraživanju da je došlo do pomaka od tradicionalne usmjerenosti na učitelja, ali još uvijek ima prostora za poboljšanje razumijevanja poučavanja i učenja kao procesa u kojemu učenik sam konstruira vlastito razumijevanje sadržaja koje uči, odnosno razumijevanja SRU-a. Stoga hipoteza o tradicionalnoj percepciji poučavanja i učenja nije u potpunosti potvrđena.

Očekivano, učitelji su pokazali relativno visoku predanost poslu i relativno nisku razinu sagorijevanja na poslu. Dosadašnja istraživanja na uzorcima hrvatskih učitelja pokazala su da su učitelji relativno zadovoljni svojim poslom i ne doživljavaju visoke razine profesionalnoga sagorijevanja (Domović i sur., 2010; Koludrović i sur., 2009; Kuzijev i Topolovčan, 2013; Slišković i sur., 2016).

Budući da su ranija istraživanja pokazala nekonzistentne rezultate o razlikama u poticanju SRU-a s obzirom na sociodemografske varijable učitelja, tako smo i mi provjerili postojanje spomenutih razlika. Nisu utvrđene razlike u poticanju SRU-a kod učitelja s obzirom na spol, staž i razinu obrazovanja (razredna/predmetna nastava). Iako su dosadašnja, inozemna istraživanja utvrdila da učitelji do 6. razreda osnovne škole u većoj mjeri potiču SRU u odnosu na nastavnike 7. i 8. razreda osnovne škole i nastavnike srednjih škola, u našemu istraživanju nisu utvrđene razlike između učitelja razredne i nastavnika predmetne nastave. Moguće je da su razlike u rezultatima posljedica razlika u kategorizaciji razina obrazovanja $\mathrm{u}$ Hrvatskoj i drugim zemljama. S druge strane, moguće je da reforme obrazovanja koje se u Hrvatskoj provode posljednjih godina, a koje se temelje na pristupu usmjerenome na učenika, dovode do ujednačavanja prakse učitelja razredne i predmetne nastave. To bi svakako trebalo detaljnije ispitati u budućim istraživanjima. Rezultati našega istraživanja u skladu su s rezultatima dosadašnjih istraživanja koja nisu utvrdila značajne efekte sociodemografskih obilježja učitelja na poticanje SRU-a (Lombaerts i sur., 2009; Vandevelde i sur., 2012) te onih koji potvrđuju da su neke druge učiteljske karakteristike, kao što su učiteljska uvjerenja i samoefikasnost, važnije za razlike u poticanju SRU-a (De Smul i sur., 2018; Moos i Ringdal, 2012). Na tome tragu utvrđene su razlike u učiteljskim percepcijama poučavanja i učenja, preciznije, u percipiranju poučavanja i učenja kao procesa vođenja i modeliranja, ali samo s obzirom na učiteljski staž. Pokazalo se da učitelji s najmanje staža (do 5 godina) u većoj mjeri poučavanje vide kao proces vođenja i 
modeliranja nego učitelji s najviše staža, što je djelomično u skladu sa zaključkom Zoharove (2004) koja izvještava da većina učitelja, posebice početnici, percipiraju proces poučavanja i učenja kao učitelju usmjerene aktivnosti. Razlike s obzirom na sociodemografska obilježja učitelja mnogo su izraženije kad je riječ o učiteljskoj predanosti poslu i sagorijevanju na poslu. Pokazalo se da su učitelji manje predani poučavanju i profesiji nego učiteljice, što je u skladu s drugim istraživanjima (Guarino i sur., 2006; Ingersoll i sur., 1997; Rots i sur., 2014). Naše je istraživanje također pokazalo da učitelji doživljavaju veću razinu otuđenosti nego učiteljice. Ti su rezultati u skladu s rezultatima drugih autora koji su utvrdili da je sagorijevanje, odnosno depersonalizacija izraženija kod muškaraca (Domović i sur., 2010; Kuzijev i Topolovčan, 2013; Özer i Beycioglu, 2010). Također su utvrđene razlike u predanosti poučavanju i profesiji te otuđenosti s obzirom na učiteljski staž. Najmanju predanost poučavanju i profesiji te najveću razinu otuđenosti pokazuju učitelji sa 6 15 godina staža. Iako neka druga istraživanja pokazuju da učitelji s više godina staža pokazuju manje razine predanosti (Ingersoll i sur., 1997) te više razine iscrpljenosti i otuđenosti (Domović i sur., 2010; Slišković i sur., 2016), naše je rezultate možda moguće objasniti pozicijom učitelja u toj fazi profesionalnoga razvoja. Day i suradnici (2007) objašnjavaju profesionalni razvoj učitelja u šest faza, a fazu od 8 do 15 godina radnoga staža nazivaju fazom tranzicije i rješavanja napetosti. Svaka faza ima dvije orijentacije, uspješnoga i neuspješnog suočavanja, pa tako i ta. Neuspješno suočavanje u toj je fazi obilježeno padom motivacije, osjećajem neuspjeha i razmišljanja o napuštanju karijere. Moguće je da u toj fazi profesionalnoga razvoja učitelja dolazi i do poteškoća u usklađivanju privatne (obitelj, briga o vlastitoj djeci) i radne uloge, pogotovo kad znamo da je uglavnom riječ o ženama. Nakraju, utvrđene su razlike u predanosti i sagorijevanju kod učitelja razredne i učitelja predmetne nastave. Veću predanost školi i učenicima te poučavanju i profesiji pokazuju učitelji razredne nastave, što je u skladu s dosadašnjim rezultatima. Npr. Heyns (1988) utvrdio je da je vjerojatnije da će učitelji u nižim razredima ostati u poučavanju, dok su Fresko i suradnici (1997) utvrdili indirektan utjecaj obrazovne razine na predanost preko zadovoljstva poslom. Učitelji nižih razreda zadovoljniji su svojim statusom, plaćom i radnim uvjetima pa su onda i predaniji poslu (Fresko i sur., 1997). Utvrđeno veće sagorijevanje na poslu kod učitelja predmetne nastave u skladu je s rezultatima do kojih su došli Kuzijev i Topolovčan (2013) te Koludrović i suradnice (2009).

Procjena važnosti poticanja SRU-a i samoprocjena poticanja SRU-a povezane su s percepcijom poučavanja i učenja kao osnaživanja i poticanja razvoja učenika te s predanošću i sagorijevanjem na poslu. Preciznije, učitelji koji poticanje SRU-a smatraju važnim za suvremenu praksu, kao i oni koji smatraju da potiču SRU kod svojih učenika, percipiraju poučavanje i učenje kao osnaživanje i poticanje razvoja učenika, predaniji su školi i učenicima, poučavanju i profesiji te su manje otuđeni i iscrpljeni na poslu. Dominantna percepcija poučavanja i učenja kao osnaživanja (aktivnosti usmjerene prema učeniku) pokazala je povezanost s poticanjem SRU-a, što je očekivano. Ostali su nalazi također u skladu s rezultatima dosadašnjih istraživanja prema kojima se predaniji učitelji više trude, spremniji su na inovacije i 
integriranje novih ideja u praksu (Thien i sur., 2014). Također, učitelji s niskom razinom sagorijevanja mogu se bolje posvetiti svojemu poslu, što utječe na kvalitetu poučavanja (Koludrović i sur., 2009). Serratore (2015) utvrdio je i negativan odnos između stresa na poslu i poticanja SRU-a.

Sociodemografska obilježja učitelja nisu se pokazala značajnim prediktorima ni procjene važnosti ni samoprocjene poticanja SRU-a. Nešto veći samostalni doprinos pokazale su učiteljske percepcije poučavanja i učenja, a najveći predanost poslu i sagorijevanje. Zapravo su samostalni najsnažniji prediktori procjene važnosti poticanja SRU-a veća predanost školi i učenicima, slabije izražena percepcija poučavanja kao transmisije znanja i izraženije percepcije poučavanja kao procesa modeliranja i osnaživanja, a poticanja SRU-a predanost školi i učenicima te percepcija poučavanja kao procesa osnaživanja i poticanja razvoja učenika. Iako bismo očekivali da percepcija poučavanja i učenja kao konstrukcije vlastitoga znanja najsnažnije pridonosi objašnjenju poticanja samoregulacije učenja, to u ovome istraživanju nije slučaj. Moguće je da tekstualna metafora korištena u ovome istraživanju kod učitelja izaziva asocijaciju na potpuni izostanak učiteljske uloge, što im nije prihvatljivo.

Provedeno je istraživanje pokazalo da učitelji poticanje SRU-a u suvremenoj nastavi smatraju izuzetno važnim te da i sami kod učenika potiču SRU. Međutim, te visoke samoprocjene nisu potpuno usklađene $\mathrm{s}$ učiteljskim percepcijama o poučavanju i učenju iako je dominantna percepcija poučavanja i učenja kao procesa osnaživanja i poticanja razvoja učenika (učeniku usmjerene aktivnosti), što predstavlja odmak od tradicionalnih aktivnosti usmjerenih na učitelja. Sociodemografske karakteristike učitelja nisu se pokazale važnim čimbenikom poticanja SRU-a, ali jesu za predanost i sagorijevanje na poslu. Učiteljski staž pokazao je slab, ali značajan odnos s percepcijama o poučavanju i učenju. Učitelji s najmanje učiteljskoga staža imaju najizraženije tradicionalne percepcije poučavanja i učenja. Učiteljska uvjerenja, preciznije, dominantna percepcija poučavanja kao procesa osnaživanja, povezana je s većim poticanjem SRU-a, kao i veća predanost i slabije sagorijevanje na poslu. Najsnažniji su prediktori poticanja SRU-a veća predanost školi $\mathrm{i}$ učenicima te percepcija poučavanja i učenja kao procesa osnaživanja i poticanja razvoja učenika. Istraživanje pridonosi razumijevanju učiteljskog poticanja SRU-a, kao i uloge sociodemografskih čimbenika, učiteljskih uvjerenja, predanosti i sagorijevanja na poslu u njegovu objašnjenju.

Provedeno istraživanje ima određena ograničenja. Rezultate nije moguće generalizirati jer su dobiveni na prigodnome uzorku. Korištenje različitih pristupa $u$ prikupljanju podataka (samoprocjene i metafore) omogućuje bolji uvid u razumijevanje mjerenoga konstrukta, nedostaci samoprocjena kompenziraju se prednošću metafora. Međutim, u ovome istraživanju učiteljske su percepcije mjerene s po jednom tvrdnjom pa bi u budućim istraživanjima trebalo koristiti cjelovit mjerni instrument $\mathrm{s}$ provjerenim metrijskim karakteristikama. Skala poticanja samoreguliranoga učenja pokazala je jednofaktorsku strukturu usprkos teorijskoj 
podlozi o različitim fazama i komponentama SRU-a te bi u budućim istraživanjima trebalo dodatno provjeriti njezinu valjanost. Dobivene su visoke korelacije između procjene važnosti i procjene poticanja SRU-a, što je vrlo vjerojatno posljedica tendencije nastavnika da se procjenjuju u pozitivnijemu svjetlu. Također je dobivena visoka negativna korelacija između predanosti poučavanju i profesiji i otuđenosti, što bi moglo ukazivati na to da te dvije mjere mjere isti konstrukt. Istraživanje je korelacijske prirode te bi u budućim istraživanjima (potencijalno longitudinalnima) trebalo ispitati mehanizme u osnovi utvrđenih odnosa, ispitati učiteljska znanja o poticanju SRU-a, potencijalni utjecaj obilježja učenika i podrške škole u implementaciji poticanja SRU-a. Također bi bilo korisno prikupiti i usporediti samoprocjene učitelja i procjene učenika o poticanju SRU-a.

Međutim, istraživanje ima i važnih implikacija za praksu. Istraživanja pokazuju da su znanja o SRU-u, učiteljska uvjerenja o poučavanju i učenju te učiteljska praksa (poticanje SRU-a) ključne dimenzije profesionalnoga rasta učitelja (Kramarski i Michalsky, 2009), ali i ishoda učenja kod učenika. Stoga je potrebno kroz edukacije učitelja, a posebice $u$ inicijalnome obrazovanju, jačati znanja u području razumijevanja samoregulacije učenja, razvijati konstruktivistička uvjerenja o poučavanju i učenju te utjecati na razvoj vještina SRU-a kod učitelja, odnosno načina (direktnoga i indirektnog) poticanja SRU-a. Utjecaj na učitelje tijekom inicijalnoga obrazovanja pokazao se najučinkovitijim, ali učinkovitima su se pokazali i programi namijenjeni učiteljima u praksi. Provedeno istraživanje također ukazuje na važnost predanosti i sagorijevanja na poslu u poticanju SRU-a, gdje obrazovne politike trebaju osigurati čimbenike koji će pridonositi predanosti i niskoj razini stresa kod učitelja.

\section{Literatura}

Boekaerts, M. (2002). Bringing about change in the classroom: Strengths and weaknesses of the self-regulated learning approach - EARLI presidential address, 2001. Learning and Instruction, 12(6), 589-604. https://doi.org/10.1016/S0959-4752(02)00010-5

Boekartes, M. i Corno, L. (2005). Self-regulation in the classroom: A perspective on assessment and intervention. Applied Psychology: An International Review, 54(2), 199231. https://doi.org/10.1111/j.1464-0597.2005.00205.x

Brković, I., Keresteš, G. i Kuterovac-Jagodić, G. (2012). Usporedba rezultata transverzalnoga i longitudinalnoga pristupa procjeni razvoja samoregulacije u ranoj adolescenciji. Psihologijske teme, 21(2), 273-297.

Burić, I. i Slišković, A. (2018). Oldenburški upitnik sagorijevanja. U: A. Slišković, I. Burić, V. Ćubela Adorić, M. Nikolić i I. Tucak Junaković (Ur.). Zbirka psihologijskih skala $i$ upitnika, svezak 9. (str. 13-20). Sveučilište u Zadru.

Day, C., Sammons, P., Stobart, G., Kington, A. i Gu, Q. (2007). Teachers matter. Open University Press. 
De Smul, M., Heirweg, S., Devos, G. i Van Keer, H. (2018). School and teacher determinants underlying teachers' implementation of self-regulated learning in primary education. Research Papers in Education, 34, 701-724 https://doi.org/10.1080/02671522. 2018.1536888

Dignath, C. i Büttner, G. (2008). Components of fostering self-regulated learning among students. A meta-analysis on intervention studies at primary and secondary school level. Metacognition and Learning, 3(3), 231-264. https://doi.org/10.1007/s11409-008-9029-x

Dignath, C., Buettner, G. i Langfeldt, H. P. (2008). How can primary school students learn self-regulated learning strategies most effectively? A meta-analysis on self-regulation training programmes. Educational Research Review, 3, 101-129. https://doi.org/10. 1016/j.edurev.2008.02.003

Dignath-van Ewijk, C. i van der Werf, G. (2012). What teachers think about self-regulated learning: Investigating teacher beliefs and teacher behavior of enhancing students' selfregulation. Education Research International, 741713. https://doi.org/10.1155/2012/ 741713

Domović, V., Martinko, J. i Jurčec, L. (2010). Čimbenici učiteljskog sagorijevanja na poslu. Napredak, 151(3-4), 350-369.

Domović, V. i Vizek Vidović, V. (2013). Uvjerenja studentica učiteljskoga fakulteta o ulozi učitelja, učenika i poučavanju. Sociologija i prostor, 51(3), 493-508.

Duckworth, K., Akerman, R., MacGregor, A., Salter, E. i Vorhaus, J. (2009). Self-regulated learning: A literature review. Centre for Research on the Wider Benefits of Learning Institute of Education.

Elmas, R., Demirdöğen, B. i Geban, Ö. (2011). Preservice chemistry teachers’ images about science teaching in their future classrooms. Hacettepe University Journal of Education, 40, 164-175.

Fresko, B., Kfir, D. i Nasser, F. (1997). Predicting teacher commitment. Teaching and Teacher Eduation, 13(4), 429-438. https://doi.org/10.1016/S0742-051X(96)00037-6

Guarino, C. M., Santibanez, L. i Daley, G. A. (2006). Teacher recruitment and retention: A review of the recent empirical literature. Review of Educational Research, 76, 173-208. https://doi.org/10.3102/00346543076002173

Hargreaves, A. (2005). Educational change takes ages: Life, career and generational factors in teachers' emotional responses to educational change. Teaching and Teacher Education, 21, 967-983. https://doi.org/10.1016/j.tate.2005.06.007

Hadwin, A. i Oshige, M. (2011). Self-regulation, coregulation, and socially shared regulation: Exploring perspectives of social in self-regulated learning theory. Teachers College Record, 113(2), 240-264.

Heyns, B. (1988). Educational defectors: A first look at teacher attrition in the NLS-72. Educational Researcher, 17, 24-32. https://doi.org/10.2307/1174830

Ingersoll, R. M., Alsalam, N., Quinn, P. i Bobbitt, S. (1997). Teacher professionalization and teacher commitment: A multilevel analysis. National Centre for Education Statistics. 
Kramarski, B. i Michalsky, T. (2009). Investigating preservice teachers' professional growth in self-regulated learning environments. Journal of Educational Psychology, 101(1), 161-175. https://doi.org/10.1037/a0013101

Koludrović, M., Jukić, T. i Reić Ercegovac, I. (2009). Sagorijevanje na poslu kod učitelja razredne i predmetne nastave te srednjoškolskih učitelja. Život $i$ škola, 22(2), 235-249.

Kuzijev, J. i Topolovčan, T. (2013). Uloga odabira učiteljske profesije i samopoštovanja u sagorijevanju učitelja u osnovnoj školi. Andragoški glasnik, 17(2), 125-144.

Lea, S. J., Stephenson, D. i Troy, J. (2003). Higher education students' attitudes to studentcentred learning: Beyond 'educational bulimia'. Studies in Higher Education, 28, 321334. https://doi.org/10.1080/03075070309293

Leutwyler, B. i Maag Merki, K. (2009). School effects on students' self-regulated learning. A multivariate analysis of the relationship between individual perceptions of school processes and cognitive, metacognitive, and motivational dimensions of self-regulated learning. Journal for Educational Research Online, 1(1), 197-223. https://doi:10. 5167/uzh-29038

Lombaerts, K., Engels, N. i Vanderfaeillie, J. (2007). Exploring teachers' actions to promote self-regulated learning practices in primary school. The Educational and Developmental Psychologist, 24(2), 4-24. https://doi.org/10.1017/S0816512200029187

Lombaerts, K., Engels, N. i Van Braak, J. (2009). Determinants of teachers' recognitions of self-regulated learning practices in elementary education. The Journal of Educational Research, 102(3), 163-173. https://doi.org/10.3200/JOER.102.3.163-174

Massengill, D., Barry, A. i Mahilos, M. (2008). Preservice teachers' metaphors of teaching in relation to literacy beliefs. Teachers and Teaching: Theory and Practice, 14(1), 35-50. https://doi.org/10.1080/13540600701837632

Montalvo, F. T. i Torres, M. C. G. (2004). Self-regulated learning: Current and future directions. Electronic Journal of Research in Educational Psychology, 2(1), 1696-2095.

Moos, D. C. i Ringdal, A. (2012). Self-regulated learning in the classroom: A literature review on the teacher's role. Educational Research International, 2012, 423284. https://dx.doi.org/10.1155/2012/423284

Nikčević-Milković, A. i Tatalović Vorkapić, S. (2020). Osobine ličnosti učenika, strategije samoregulacije učenja i suočavanja sa školskim neuspjehom, dob i rod kao prediktori objektivnog i subjektivnog školskog uspjeha. Psihologijske teme, 29(3), 483-506. https://doi.org/10.31820/pt.29.3.1

OECD (2009). Creating effective teaching and learning environments. First results from TALIS. https://www.oecd.org/education/school/43023606.pdf

Özer, N. i Beycioglu, K. (2010). The relationship between teacher professional development and burnout. Procedia Social and Behavioral Sciences, 2, 4928-4932. https://doi:10. 1016/j.sbspro.2010.03.797 
Pajares, F. (1992). Teachers' beliefs and educational research: Cleaning up a messy construct. Review of Educational Research, 62(3), 307-332. https://doi.org/10.3102/ 00346543062003307

Paris, S. G. i Winograd, P. (2001). The role of self-regulated learning in contextual teaching: Principles and practices for teacher preparation. Office of Educational Research and Improvement. https://files.eric.ed.gov/fulltext/ED479905.pdf

Peeters, J., De Backer, F., Kindekens, A., Jacquet, W. i Lombaerts, K. (2015, 16.-20. travnja). Mechanisms underlying primary school teachers' promotion of self-regulated learning [Prezentacija rada]. Annual meeting of the American Educational Research Association, Chicago, SAD.

Perry, N. E., Phillips, L. i Hutchinson, L. (2006). Mentoring student teachers to support selfregulated learning. The Elementary School Journal, 106(3), 237-254. https://doi.org/10. $1086 / 501485$

Raffaelli, M., Crockett, L. i Shen, Y. (2005). Developmental stability and change in selfregulation from childhood to adolescence. The Journal of Genetic Psychology, 166(1), 54-75. https://doi.org/10.3200/GNTP.166.1.54-76

Rots, I., Aelterman, A. i Devos, G. (2014). Teacher education graduates' choice (not) to enter the teaching profession: Does teacher education matter? European Journal of Teacher Education, 37(3), 279-294. https://doi.org/10.1080/02619768.2013.845164

Saban, A., Kocbeker, B. N. i Saban, A. (2007). Prospective teachers' conceptions of teaching and learning revealed through metaphor analysis. Learning and Instruction, 17, 123139. https://doi.org/10.1016/j.learninstruc.2007.01.003

Serratore, N. (2015). Teaching towards self-regulation: The impact of stress, self-efficacy, and motivation. [Undergraduate Honors Theses]. Western University. https://ir.lib.uwo.ca/psychK_uht/19

Slišković, A., Burić, I. i Knežević, I. (2016). Zadovoljstvo poslom i sagorijevanje na poslu kod učitelja: Važnost podrške ravnatelja i radne motivacije. Društvena istraživanja, 25(3), 371-392. https://doi.org/10.5559/di.25.3.05

Spruce, R. i Bol, L. (2015). Teacher beliefs, knowledge, and practice of self-regulated learning. Metacognition Learning, 10, 245-277. https://doi10.1007/s11409-014-9124-0

Šimić Šašić, S. (2012). Kvaliteta interakcije nastavnika i učenika na različitim razinama obrazovanja. [Neobjavljena doktorska disertacija]. Filozofski fakultet, Sveučilište u Zagrebu, Zagreb.

Šimić Šašić, S., Šimunić, A., Ivković, A. i Ključe, A. (2018). The correlation of perceptions of professional roles and teacher beliefs with the quality of teacher interaction. Journal of Research in Science, Mathematics and Technology Education, 1(2), 207-227. https://doi.org/10.31756/jrsmte.125

Thien, L. M., Razak, N. A. i Ramayah, T. (2014). Validating teacher commitment scale using a Malaysian sample. Sage Open, 1-9. https://doi.org/10.1177/2158244014536744 
Trigwell, K. i Prosser, M. (2004). Development and use of the Approaches to Teaching Inventory. Educational Psychology Review, 16(4), 409-424. https://doi.org/10.1007/ s10648-004-0007-9

Trigwell, K., Prosser, M. i Waterhouse, F. (1999). Relations between teachers' approaches to teaching and students' approaches to learning. Higher Education, 37, 57-70. https://doi.org/10.1023/A:1003548313194

Tsui, K. T. i Cheng, Y. C. (1999). School organisational health and teacher commitment: A contingency study with multi-level analysis. Educational Research and Evaluation, 5, 249-268. https://doi.org/10.1076/edre.5.3.249.3883

Vandevelde, S., Vandenbussche, L. i Van Keer, H. (2012). Stimulating self-regulated learning in primary education: Encouraging versus hampering factors for teachers. ProcediaSocial and Behavioral Sciences, 69, 1562-1571. https://10.1016/j.sbspro.2012.12.099

Woolfolk Hoy, A., Davis, H. i Pape, S. J. (2006). Teacher knowledge and beliefs, U: P. Alexander i P. Winne (Ur.), Handbook of Educational Psychology (str. 715-738). Lawrence Erlbaum Associates.

Yan, Z. (2017). How teachers' beliefs and demographic variables impact on self-regulated learning instruction. Educational Studies, 44(5), 564-577. https://doi.org/10.1080/ 03055698.2017.1382331

Zimmerman, B. J. (1998). Developing self-fulfilling cycles of academic regulation: An analysis of exemplary instructional models. U: D. H. Schunk i B. J. Zimmerman (Ur.), Self-regulated learning: From teaching to self-reflective practice (str. 1-19). The Guilford Press.

Zimmerman, B. (2002). Becoming a self-regulated learner: An overview. Theory into Practice, 41(2), 64-71. https://doi.org/10.1207/s15430421tip4102_2

Zimmerman, B. J. i Schunk, D. H. (Ur). (2001). Self-regulated learning and academic achievement: Theoretical perspectives (2nd ed.). Erlbaum.

Zohar, A. (2004). Higher order thinking in science classrooms: Students' learning and teachers' professional development. Kluwer Academic Press.

Zumbrunn, S., Tadlock, J. i Roberts, E. D. (2011). Encouraging self-regulated learning in the classroom: A review of the literature. Metropolitan Educational Research Consortium (MERC). http://www.merc.soe.vcu.edu/files/2013/11/Self-RegulatedLearning-2.pdf 


\title{
Promoting Self-Regulated Learning - the Role of some Sociodemographic Factors, Teachers' Perceptions of Teaching and Learning, Commitment to Work and Work Burnout
}

\begin{abstract}
Self-regulated learning (SRL) has become an important educational goal, and as it depends on the context in which it occurs, teachers have an important role to play in encouraging the development of effective learning self-regulation strategies. The aim of the research was to examine the teacher's encouragement of SRL and its relationship with some sociodemographic characteristics of teachers (gender, length of service, educational level), teachers' perceptions of teaching and learning, commitment to work and burnout at work. The research was conducted on a sample of 299 primary and secondary school teachers. The following measurement instruments were applied: SocioDemographic Survey Questionnaire, Self-Regulated Learning Encouragement Scale, Teacher Perceptions on Teaching and Learning Questionnaire, Teacher Commitment Scale and Oldenburg Burnout Questionnaire. The results showed that teachers consider the promotion of SRL is important in modern teaching and that they encourage SRL in working with students. Teaching and learning are predominantly perceived as a process of empowering and encouraging student development (student-centred activities) which is a departure from traditional teacher-centred activities. No differences were found in encouraging SRL with respect to teachers 'sociodemographic characteristics, but some differences were found in teachers' perceptions, commitment to work, and burnout. The connection between encouraging SRL and the dominant perception of teaching and learning, as well as commitment to work and burnout at work, has been established. The strongest predictors of encouraging SRL are commitment to school and students, and the perception of teaching and learning as a process of empowering and encouraging development in students.
\end{abstract}

Keywords: encouraging self-regulated learning, commitment to work, burnout at work, sociodemographic characteristics of teachers, teachers' perceptions of teaching and learning

Primljeno: 22.9. 2020. 
